\title{
Drying kinetics of baru flours as function of temperature
}

\author{
Douglas R. Reis ${ }^{1}$, Fabrício B. Brum² ${ }^{2}$ Eduardo J. O. Soares ${ }^{3}$, \\ Jessiana R. Magalhães', Fabrício S. Silva ${ }^{4} \&$ Alexandre G. Porto ${ }^{2}$ \\ ${ }^{1}$ Universidade Federal de Santa Catarina/Departamento de Engenharia Química e Alimentos/Programa de Pós-graduação em Engenharia de Alimentos. \\ Florianópolis, SC. E-mail: dougrreis@hotmail.com (Corresponding author) - ORCID: 0000-0002-9728-3822 \\ ${ }^{2}$ Universidade do Estado de Mato Grosso/Faculdade de Arquitetura e Engenharia/Departamento de Engenharia de Alimentos. Barra do Bugres, MT. E-mail: \\ fabricio_b_brum@unemat.br - ORCID: 0000-0002-3764-194X; jessianarmagalhaes@hotmail.com - ORCID: 0000-0001-7228-2826; porto@unemat.br - \\ ORCID: 0000-0002-5966-1888 \\ ${ }^{3}$ Universidade do Estado de Mato Grosso/Faculdade de Arquitetura e Engenharia/Departamento de Engenharia de Produção Agroindustrial. Barra do \\ Bugres, MT. E-mail: eduardo.oenning@unemat.br - ORCID: 0000-0002-3548-6579 \\ ${ }^{4}$ Universidade Federal do Paraná/Setor Palotina/Departamento de Engenharias e Exatas. Palotina, PR. E-mail: fabricio.silva@ufpr.br - ORCID: 0000- \\ 0003-2988-4017
}

\section{Key words:}

Dipteryx alata Vog.

chestnut vegetables proteins Midilli \& Kucuk Page

\begin{abstract}
A B S T R A C T
Several types of seeds have been initially used in the food industry due to the great potential that vegetable proteins have. Baru is a fruit commonly found in the Cerrado biome, having a high nutritional value. This paper aimed to determine and analyze the drying kinetics of whole and defatted baru almond flours at different temperatures. The flour resulting from almond milling was defatted using petroleum ether. The drying processes were performed at temperatures of 40,50 and $60{ }^{\circ} \mathrm{C}$. The mathematical models of Page, Henderson and Pabis, Midilli \& Kucuk, Thompson and Approximation of Diffusion were fitted to the experimental data. The results showed a noticeable effect of air temperature on the drying kinetics of whole and defatted baru almond flours. According to the statistical parameters of analysis, the models Midilli \& Kucuk and Page were the ones with the best fits to the experimental data. The effective diffusivity values found ranged from $8.02 \times 10^{-10}$ to $19.90 \times 10^{-10} \mathrm{~m}^{2} \mathrm{~s}^{-1}$ and for the activation energy were 22.39 and $39.37 \mathrm{KJ} \mathrm{mol}^{-1}$ for whole and defatted almonds, respectively.
\end{abstract}

\section{Palavras-chave: Dipteryx alata Vog. castanha proteínas vegetais Midilli \& Kucuk Page}

\section{Cinética de secagem de farinha da amêndoa de baru em função da temperatura}

\begin{abstract}
R E S U M O
Vários tipos de sementes têm sido introduzidos em formulações na indústria de alimentos, graças ao grande potencial que as proteínas vegetais apresentam. O baru, fruto disseminado no bioma cerrado, apresenta em sua castanha um alto valor nutricional. O presente trabalho teve como objetivo determinar e analisar a cinética de secagem da farinha integral e desengordurada da amêndoa do baru em diferentes temperaturas. A farinha resultante da moagem das amêndoas foi desengordurada por éter de petróleo. As secagens foram realizadas nas temperaturas de 40,50 e $60^{\circ} \mathrm{C}$. Os dados experimentais foram ajustados aos modelos matemáticos de Page, Henderson e Pabis, Midilli \& Kucuk, Thompson e Aproximação da Difusão. Os resultados demonstraram notável efeito da temperatura do ar na cinética de secagem da farinha integral e desengordurada da amêndoa do baru. A farinha da amêndoa integral apresentou perdas de umidade mais lentas do que a farinha desengordurada. Segundo os parâmetros estatísticos de análises, os modelos de Midilli \& Kucuk e Page foram os que obtiveram os melhores ajustes dos dados experimentais. Os valores de difusividade efetiva encontrados variaram de $8,02 \times 10^{-10}$ a $19,90 \times 10^{-10} \mathrm{~m}^{2} \mathrm{~s}^{-1}$ e para a energia de ativação foram de 22,39 e $39,37 \mathrm{KJ} \mathrm{mol}^{-1}$ para a amêndoa integral e desengordurada, respectivamente.
\end{abstract}




\section{INTRODUCTION}

The Cerrado (Brazilian savanna) is known as the second largest biome in South America. It has a typically hot and semi-humid climate in which there are several species of trees flourishing in the native flora of the region (Sousa et al., 2011; Santos et al., 2016). In this context, the fruits of native plants from the Brazilian Cerrado, such as baru (Dipteryx alata Vog.), have been standing out because they have a nutritional potential with a great sensorial and economic appeal. In addition, baru is used as raw material for the formulation of new food products. Baru seed is also named as chestnut or almond. It is rich in lipids and proteins and it is usually processed and commercialized fresh, roasted or in the form of flour, generating income for several regional communities that live in the Cerrado area, being also very valued by the international market (Takemoto et al., 2001; Rocha \& Santiago, 2009; Fernandes et al., 2010).

Taking into account the high lipid contents, baru almond defatting brings about an increase in the protein content, which can be used for the production of several products since the proteins contribute for increasing the nutritional and functional value and the technological properties of the food system (Wang et al., 1999; Ribeiro \& Seravalli, 2007).

Another method that enables the concentration of these components is drying. This technique is a complex process in which heat and the mass transfer happen concurrently, reducing moisture and leading to a substantial reduction in mass and volume of the final product. Other benefits associated with food drying are the increase in product lifetime, easiness in transportation and commercialization (Fellows, 2009; VegaGálvez et al., 2010; Bettega et al., 2014).

The drying kinetics provides a physical view of the drying process and its principle is based on building a set of mathematical equations which are able to characterize properly the moisture loss as a function of time, in an accurate and simple way, being able to describe the drying process better (Barati \& Esfahani, 2011; Rosa et al., 2015).

Until now, only a few papers about the drying kinetics of baru almond have been found in the literature (Teixeira et al., 2015); however, no study was found on the drying kinetics of whole and defatted baru almond flours, emphasizing its defatting. In this context, this paper aimed to determine and analyze the drying kinetics of whole and defatted baru almond flours at different temperatures.

\section{Material ANd Methods}

The experiments were performed in the Laboratory of Engineering and Agroindustrial Processing (LEPA) located at the university campus Deputado Estadual Renê Babour (Mato Grosso State University - UNEMAT), in Barra do Bugres, MT, Brazil. The raw material used was baru almond purchased at the local market from Mato Grosso Southwest region. The almonds were manually selected considering their physical integrity.

Almond milling was performed in a hammer-type food processor (Vieira MCO260) with a granulometric sieve of $0.7 \mathrm{~mm}$. Then, the flour obtained was defatted based on the methodology of Boatright \& Hettiarachchy (1995), adapted by substituting the hexane solvent by petroleum ether, because it is an organic solvent and volatilizes completely when exposed to ambient temperature without leaving residues.

The defatted flour and whole flour of baru chestnut were submitted to a washing process with distilled water aiming to remove the non-proteinaceous soluble fractions. Subsequently, a proteinaceous isolate was obtained from the baru almond, adapted from Carvalho et al. (2009).

Drying processes were performed under controlled air temperature conditions of 40,50 and $60^{\circ} \mathrm{C}$, in triplicate. The samples were divided into 20 -g portions and were uniformly placed in Petri dishes and then in a forced ventilation oven (Quimis Q314M242). During all the drying process, the samples were weighed periodically on an electronic scale (Bioprecisa FA2104n, 0.1 mg precision and four decimal places) until they reached a constant weight.

Moisture content at $105{ }^{\circ} \mathrm{C}$ and total lipids analyses were performed according to the Adolfo Lutz Institute (IAL, 2008) protocols.

The drying curves were obtained by converting the water loss data into the dimensionless parameter of moisture ratio (RU), Eq. 1 was used.

$$
\mathrm{RU}=\frac{\mathrm{U}-\mathrm{Ue}}{\mathrm{Ui}-\mathrm{Ue}}
$$

where:

$\mathrm{U}$ - moisture content of the product, decimal d.b.;

Ui - initial moisture content of the product, decimal d.b.; and,

Ue - equilibrium moisture content of the product, decimal d.b.

Different mathematical models were used to describe the drying rate of the process. Aiming at obtaining information about the drying kinetics of the baru almond whole and defatted flours, the curves of the moisture ratio as a function of time, were constructed for different drying air temperatures.

The drying curves of the baru almond whole and defatted flours were shown through five mathematical models (Table 1) fitted by non-linear regression using the statistical program XLSTAT (Addinsoft, 2016).

The models were fitted through non-linear regression analyses by using the Quasi-Newton method. The degree

Table 1. Mathematical models used to describe the drying process

\begin{tabular}{ll}
\hline \multicolumn{1}{c}{ Model designation } & \multicolumn{1}{c}{ Model } \\
$\begin{array}{l}\text { Page } \\
\text { (Page, 1949) }\end{array}$ & $\mathrm{RU}=\mathrm{e}^{-\mathrm{K} \mathrm{t}^{\mathrm{n}}}$ \\
$\begin{array}{l}\text { Henderson \& Pabis } \\
\text { (Henderson \& Pabis, 1961) }\end{array}$ & $\mathrm{RU}=\mathrm{a} \mathrm{e}^{-\mathrm{Kt}}$ \\
$\begin{array}{l}\text { Midilli \& Kucuk } \\
\text { (Midilli \& Kucuk, 2003) }\end{array}$ & $\mathrm{RU}=\mathrm{a} \mathrm{e}^{-\mathrm{Kt}}+\mathrm{bt}$ \\
$\begin{array}{l}\text { Thompson } \\
\text { (Thompson et al., 1968) }\end{array}$ & $\mathrm{RU}=\mathrm{e}^{\left(-\mathrm{a}-\left(\mathrm{a}^{2}+(4 \cdot \mathrm{b} \cdot \mathrm{t})^{0.5}\right) \cdot(2 \cdot \mathrm{b})\right)}$ \\
$\begin{array}{l}\text { Approximation of diffusion } \\
\text { (Ertekin \& Yaldiz, 2001) }\end{array}$ & $\mathrm{RU}=\mathrm{a} \mathrm{e}^{-\mathrm{Kt}}+(1-\mathrm{a}) \mathrm{e}^{-\mathrm{Kbt}}$ \\
\hline
\end{tabular}

$\mathrm{RU}$ - Moisture ratio of the product, dimensionless; $\mathrm{t}$ - Drying time, $\mathrm{h}$; $\mathrm{K}$ - Drying coefficients; $\mathrm{a}, \mathrm{b}, \mathrm{n}$ - Constants of the models 
of fit of each model took into account the magnitude of the determination coefficient $\left(\mathrm{R}^{2}\right)$ and the estimated average error (SE).

$$
\mathrm{SE}=\sqrt{\frac{\sum\left(\mathrm{RU}_{\mathrm{pre}}-\mathrm{RU}_{\exp }\right)^{2}}{\mathrm{~N}}}
$$

where:

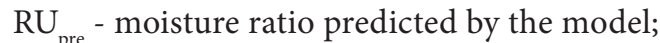

$\mathrm{RU}_{\text {exp }}^{\text {pre }}$ - experimental moisture ratio; and,

$\mathrm{N}$ - number of observations made during the experiment.

The values of average effective moisture diffusivity were determined by analytical solution of Fick's law for liquid water diffusion in on solid, taking into account the conditions of the material in question. The activation energy (Ea) was obtained from the dependence of effective diffusivity $\left(D_{e f}\right)$ on temperature, analyzed by an Arrhenius-type equation, Eq. 8 .

$$
\text { Def }=D_{o} \exp \left(-\frac{E a}{R T}\right)
$$

where:

$$
\begin{array}{ll}
\mathrm{D}_{\mathrm{o}} & \text { - pre-exponential factor, } \mathrm{m}^{2} \mathrm{~s}^{-1} ; \\
\mathrm{E}_{\mathrm{a}} & \text { - activation energy, J mol } \\
\mathrm{R} & \text { - universal gas constant, } 8.314 \mathrm{~J} \mathrm{~mol}^{-1} \mathrm{~K}^{-1} \text {; and, } \\
\mathrm{T} & \text { - absolute temperature, } \mathrm{K} .
\end{array}
$$

\section{Results AND Discussion}

The curves shown in Figure 1 (A, B) indicate the effect caused by the increase in air temperature through the drying kinetics, facilitating the energy transfer in the form of heat to the samples, which consequently increases the moisture removal rate of the product. This trend can be usually observed in drying experiments. These results are in accordance with other studies, such as Andrade et al. (2006), who worked with drying kinetics in bean seeds; Costa et al. (2011) with crambe seeds; Santos et al. (2013) with urucum flour; and Teixeira et al. (2015) with drying of whole baru almonds.

The initial moisture values found for the whole and defatted baru almond flours were 3.22 and $3.51 \%$, which are within the range found by Vera et al. (2009) from 2.93 to $5.07 \%$, Lima et al. (2010) (3.23\%) and Fernandes et al. (2010) (from 3.20 to $4.00 \%)$. After washing with distilled water, the moisture was around $68 \%$ for the whole flour and $70 \%$ for the defatted flour.

Analyzing the drying curves in Figure $1(\mathrm{C}, \mathrm{D}, \mathrm{E})$, there is an evident difference between both flours at the three evaluated temperatures, where the defatted flour reached equilibrium in less time compared with the whole flour. This effect was attributed to higher lipid content in the whole flour $(45.55 \%$ dry basis) comparing to the defatted flour (4.97\% dry basis); therefore, it became more difficult for the water to break the hydrophobic barrier formed by the lipids, which increased the drying time. These results are in accordance with those found by Cyprian et al. (2015) for the Capelin (Mallotus villossus) drying, where the moisture loss was slower for the samples with higher lipid contents.
A.

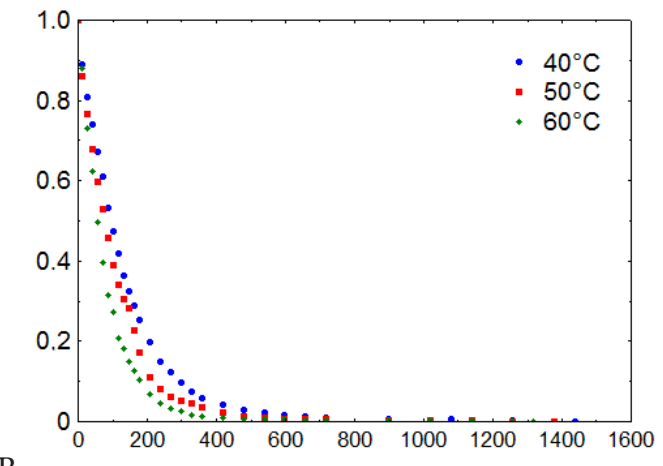

B.

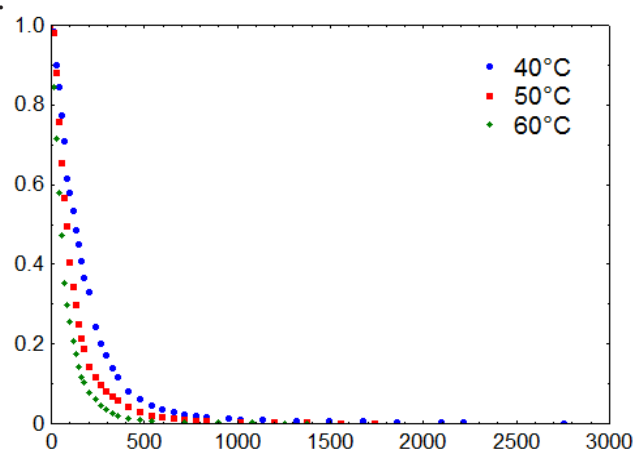

C.

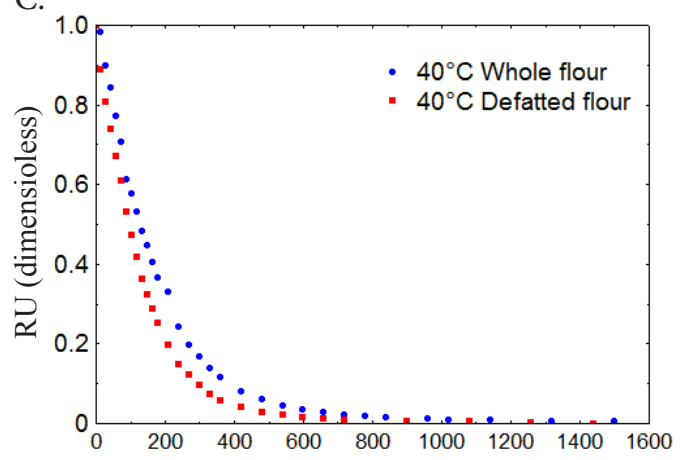

D.

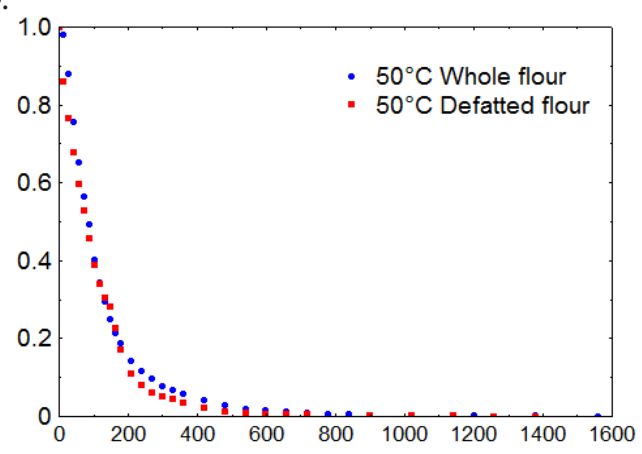

E.

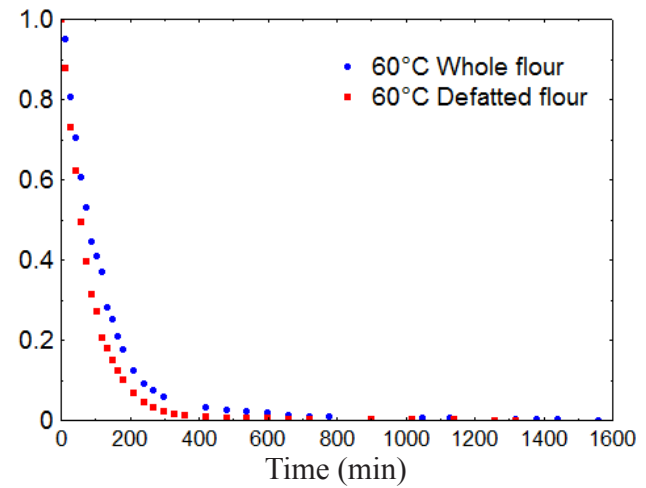

Figure 1. Drying curves of whole (A) and defatted (B) baru almond flours at $40,50,60{ }^{\circ} \mathrm{C}$ and a comparison of the two drying curves under temperatures of 40 (C), 50 (D) and $60^{\circ} \mathrm{C}(\mathrm{E})$ 
In this way, the lipid content works as a limiting factor during the drying process, acting as a physical barrier to heat transfer, which is responsible for water evaporation as well as its diffusivity from the interior to the surface of the food.

Using the dimensionless moisture data from Figure $1(\mathrm{~A}, \mathrm{~B})$, it is possible to fit them with the mathematical models shown in Table 1, as well as determine the coefficient of determination $\left(\mathrm{R}^{2}\right)$, estimated average error (SE) and verify which model is the best to represent adequately the drying process of the baru almond samples.

Table 2 shows the parameters of the mathematical models fitted to the experimental data of whole and defatted almond flours through non-linear regression at the three temperatures, as well as their coefficients of determination $\left(R^{2}\right)$ and estimated average error (SE).

It is possible to identify that, for the analyzed models, the estimated average error (SE) of the moisture ratio, which describes the value of the standard deviation for the estimate, has relatively low values. It is also possible to observe that high determination coefficients $\left(\mathrm{R}^{2}\right)$ were obtained, higher than $90 \%$, indicating a successful representation of the drying process in the studied conditions (Table 2).

As noted in Table 2, the value of the drying constant $\mathrm{k}$ increased with the temperature rise in almost all samples, which occurs because higher temperatures result in higher drying rates, reaching the equilibrium content in a shorter process time. These results were also observed by Corrêa et al. (2010) with coffee drying.
All models fitted well to the experimental data, mainly the Midilli \& Kucuk model for the whole flour and Page model for the defatted flour, since both had $\mathrm{R}^{2}$ values closer to $100 \%$ of the curve fitting and lower SE value for the samples.

The Figure 2 shows a graphical representation of the mathematical models which fitted best to the data for both types of samples at the three temperatures.

Based on the parameters found through the best data fits with the mathematical models, an analytical procedure was done and it was possible to represent graphically the moisture variation rate in relation to time in both raw materials, shown in Figure 3.

The curves in Figure 3 (A, C, E) describe the moisture loss rate in relation to time, highlighting a meaningful difference in the drying kinetics of the whole flour compared to the defatted flour. The comparison of moisture loss between both raw materials is represented in Figure 3 (B, D, F). This difference is related to the lipid content of the sample, since the whole flour showed a lipid content of $45.55 \%$ (dry basis) and the defatted flour of $4.97 \%$ (dry basis). These aspects are in accordance with the experiment done by Cyprian et al. (2015).

Using the Fick's law equation (Eq. 8) for products with a flat plate geometric shape, the values of the effective diffusivity were calculated from the experimental data. The effective diffusion coefficient values increased when the drying air temperature increased, which demonstrates a reduction of the internal resistances to the drying processes. They were $11.90 \times 10^{-10}$ and $8.02 \times 10^{-10}\left(40^{\circ} \mathrm{C}\right), 15.30 \times 10^{-10}$ and $12.90 \times 10^{-10}\left(50^{\circ} \mathrm{C}\right)$; and 19.90 $\times 10^{-10}$ and $19.50 \times 10^{-10}\left(60^{\circ} \mathrm{C}\right)$ for WBF and DBF, respectively.

Table 2. Mathematical models fitted to the experimental data at drying temperatures of 40,50 and $60{ }^{\circ} \mathrm{C}$ for whole and defatted baru almond flours

\begin{tabular}{|c|c|c|c|c|c|c|c|c|}
\hline Model & $T$ & Sample & A & b & $\mathrm{K}$ & $\bar{n}$ & $\mathrm{R}^{2}$ & SE \\
\hline \multirow{5}{*}{ Henderson \& Pabis (1961) } & 40 & WBF & 1.0171 & - & 0.0075 & - & 99.926 & 0.0122 \\
\hline & 40 & DBF & 1.0771 & - & 0.0059 & - & 99.877 & 0.0165 \\
\hline & 50 & WBF & 1.0050 & - & 0.0090 & - & 99.901 & 0.0135 \\
\hline & 60 & WBF & 1.0384 & - & 0.0126 & - & 99.901 & 0.0129 \\
\hline & 60 & DBF & 1.0151 & - & 0.0130 & - & 99.908 & 0.0124 \\
\hline \multirow{5}{*}{ Approximation of Diffusion (2001) } & 40 & WBF & 0.0615 & 0.99844 & 0.0075 & - & 99.926 & 0.2647 \\
\hline & 50 & WBF & -0.1999 & 0.56652 & 1.0401 & - & 99.928 & 0.1848 \\
\hline & 50 & DBF & -0.6382 & 0.49000 & 1.4646 & - & 99.857 & 0.3693 \\
\hline & 60 & WBF & -0.9141 & 0.76206 & 1.1902 & - & 99.931 & 0.2036 \\
\hline & 60 & DBF & -1.0933 & 0.93918 & 0.8812 & - & 99.910 & 0.3873 \\
\hline \multirow{5}{*}{ Midilli \& Kucuk (2003) } & 40 & WBF & 0.9888 & 0.000005 & 0.0045 & 1.09 & 99.972 & 0.0075 \\
\hline & 40 & DBF & 1.0462 & 0.000017 & 0.3192 & 1.08 & 99.940 & 0.2885 \\
\hline & 50 & WBF & 0.9895 & 0.000002 & 0.0071 & 1.04 & 99.964 & 0.0126 \\
\hline & 60 & WBF & 1.0107 & 0.000004 & 0.0076 & 1.10 & 99.961 & 0.0084 \\
\hline & 60 & DBF & 1.4424 & 0.00035 & 0.7341 & 1.04 & 99.640 & 0.0383 \\
\hline \multirow{6}{*}{ Page (1949) } & 40 & WBF & - & - & 0.0047 & 1.05 & 99.959 & 0.0091 \\
\hline & 40 & DBF & - & - & 0.0036 & 1.07 & 99.880 & 0.0161 \\
\hline & 50 & WBF & - & - & 0.0076 & 1.03 & 99.917 & 0.0124 \\
\hline & 50 & DBF & - & - & 0.0039 & 1.15 & 99.730 & 0.0236 \\
\hline & 60 & WBF & - & - & 0.0087 & 1.07 & 99.936 & 0.0104 \\
\hline & 60 & DBF & - & - & 0.0112 & 1.02 & 99.909 & 0.0123 \\
\hline \multirow{6}{*}{ Thompson (1968) } & 40 & WBF & -140.541 & -3.42910 & - & - & 99.940 & 0.0110 \\
\hline & 40 & DBF & -94.4188 & 78.73540 & - & - & 97.592 & 0.0728 \\
\hline & 50 & WBF & -114.771 & -1.89411 & - & - & 99.916 & 0.0125 \\
\hline & 50 & $\mathrm{DBF}$ & -52.7379 & 43.73245 & - & - & 96.549 & 0.2036 \\
\hline & 60 & WBF & -80.1935 & -0.38929 & - & - & 99.830 & 0.0170 \\
\hline & 60 & DBF & -72.2937 & 3.386105 & - & - & 99.868 & 0.0149 \\
\hline
\end{tabular}

WBF - Whole baru flour; DBF - Defatted baru flour; K - Drying coefficients; A, b, $n$ - Constants of the models; $\mathrm{R}^{2}$ - Magnitude of the coefficient of determination; SE - Estimated average error; $\mathrm{T}$ - Temperature ${ }^{\circ} \mathrm{C}$ 

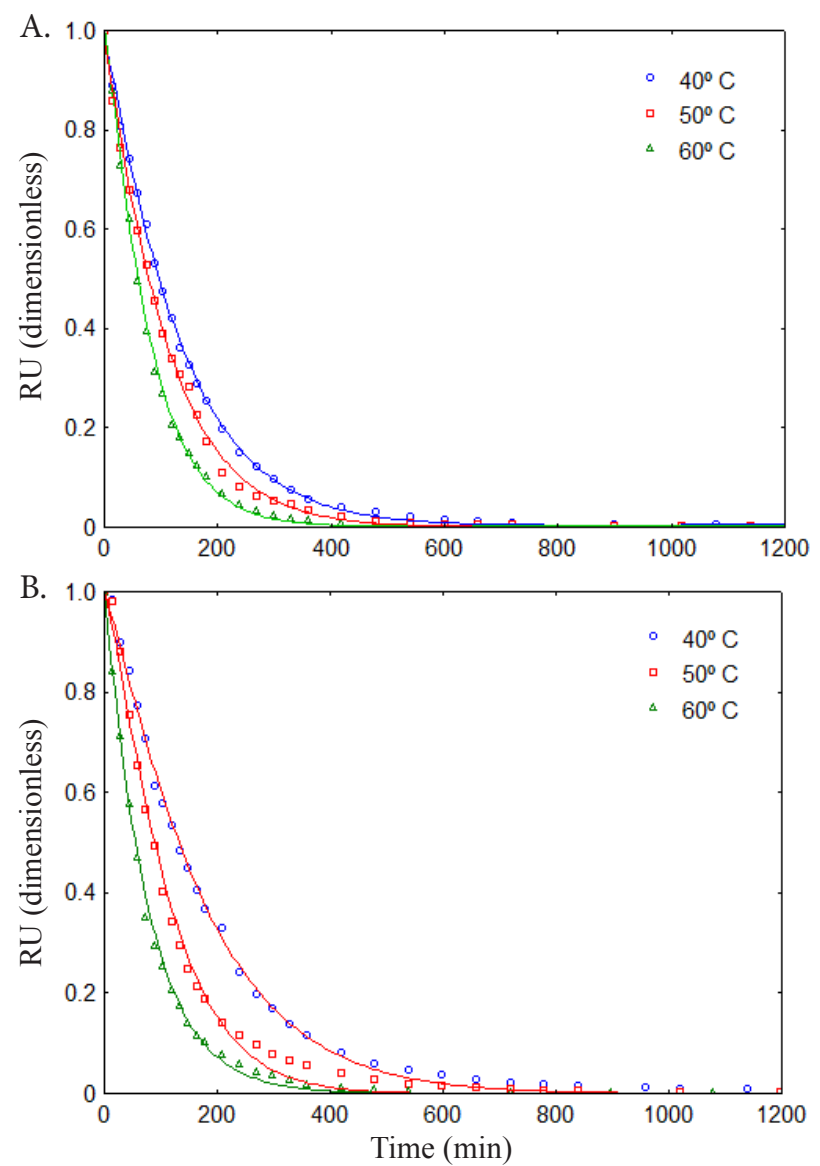

Figure 2. Adjustment moisture ratio (RU) to the Midilli \& Kucuk model for drying of whole baru almond flour (A) and to the Page model for drying of defatted baru almond flour (B) at the three temperatures evaluated

Teixeira et al. (2015) evaluated the whole baru almond drying kinetics and obtained diffusivity values from $18.15 \mathrm{x}$ $10^{-11}$ to $37.08 \times 10^{-11} \mathrm{~m}^{2} \mathrm{~s}^{-1}$ for the temperatures of 50,60 and
$70{ }^{\circ} \mathrm{C}$, showing that the diffusivity values also increased when the drying temperature increased. Almeida et al. (2009) dried beans of the adzuki variety in the temperature range from 30 to $70^{\circ} \mathrm{C}$ and obtained diffusion coefficients from $0.510 \times 10^{-10}$ to $2.230 \times 10^{-10} \mathrm{~m}^{2} \mathrm{~s}^{-1}$ for 30 and $70^{\circ} \mathrm{C}$, respectively. For Jittanit (2011), the effective diffusion coefficient is dependent on the drying air temperature as well as factors such as variety and composition of materials. Gazor \& Mohsenimanesh (2010) studying canola beans drying, found effective diffusivity values ranging from $3.76 \times 10^{-11}$ to $8.46 \times 10^{-11} \mathrm{~m}^{2} \mathrm{~s}^{-1}$ for the temperature range from 30 to $100^{\circ} \mathrm{C}$.

Figure $4 \mathrm{~A}$ shows a graphical representation for the effective diffusivity $\left(\mathrm{D}_{\text {ef }} \times 10^{-10}\right)$ as a function of air temperature. After obtaining the effective moisture diffusivity values, it was possible to calculate the activation energy values using Arrhenius representation (Figure 4B).

It is noticeable in Figure $4 \mathrm{~A}$ a higher difference between the samples at the temperatures of 40 and $50^{\circ} \mathrm{C}$; consequently, when the drying temperature increases the $\mathrm{D}_{\text {ef }}$ values of both flours tend to be similar.

For Kashaninejad et al. (2007), the activation energy is a barrier that needs to be crossed, so the diffusion process can occur in the product. In this paper, the activation energies found for the drying process were 22.39 and $39.37 \mathrm{KJ} \mathrm{mol}^{-1}$ and the coefficients of determination were of 99.95 and $99.98 \%$ for the whole and defatted almond flours. These values were close to that found by Silva et al. (2008) for cowpea, of $26.90 \mathrm{KJ} \mathrm{mol}^{-1}$. Doymaz (2005) working with green beans and Corrêa et al. (2006) with beans of the red group obtained the values of 35.43 and $40.08 \mathrm{KJ} \mathrm{mol}^{-1}$, respectively.

In the drying processes the lower activation energy, the higher the water diffusivity in the product. Therefore, the activation energy obtained is within the range shown by Zogzas et al. (1996) for agricultural products, ranging from
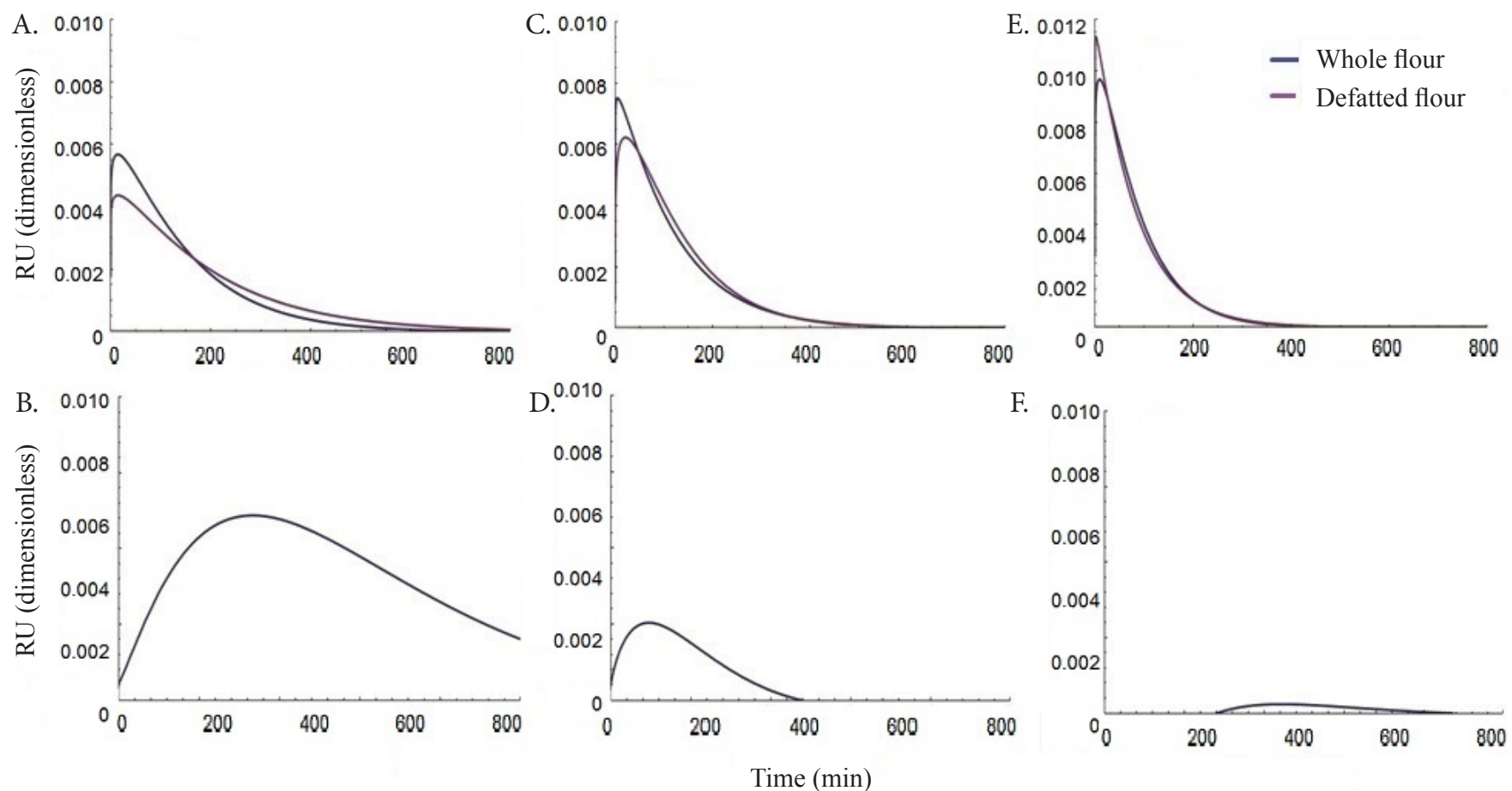

Figure 3. Moisture ratio (RU) variation rate with respect to time of whole and defatted baru almond flours, at 40 (A, B), $50(\mathrm{C}, \mathrm{D})$ and $60{ }^{\circ} \mathrm{C}(\mathrm{E}, \mathrm{F})$ 

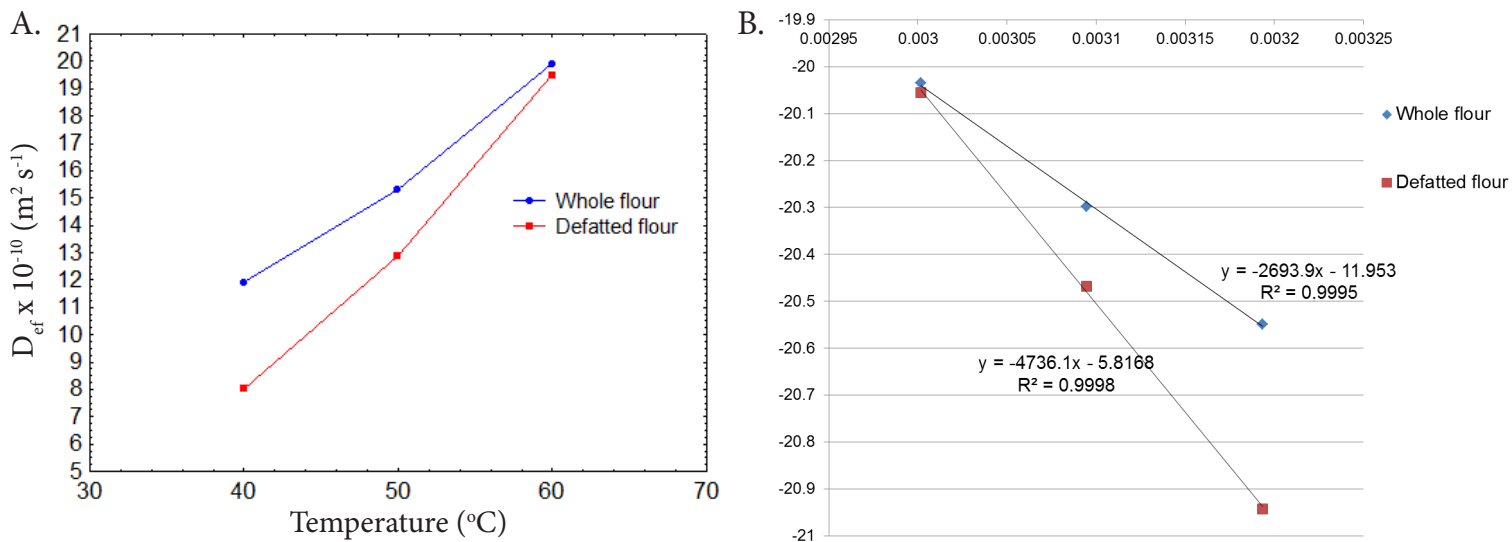

Figure 4. Graphic representation for the effective diffusivity $\left(D_{\text {ef }} \times 10^{-10}\right)$ as a function of the drying air temperature $(A)$ and Arrhenius representation for the effective diffusion coefficient (B) for both baru flours

12.70 to $110 \mathrm{KJ} \mathrm{mol}^{-1}$. In general, it is possible to say that the higher the temperature, the faster the activation energy will be overcome and, consequently, the food begins to lose its moisture more quickly.

\section{Conclusions}

1. The increase in the drying temperature led to higher water removal rates of the product.

2. The flour of whole almond showed slower moisture loss than the defatted flour and the lipid content acted as a limiting factor during the drying process.

3. The Midilli \& Kucuk model had the best results for the whole flour and Page model had the best fits for the defatted flour.

4. The defatting contributed to the reduction of the drying time of the samples, being the most indicated process to be executed industrially.

\section{ACKNOWLEDGEMENTS}

To the Mato Grosso Research Support Foundation (FAPEMAT) for the financial support and to the National Council for Scientific and Technological Development (CNPq) for granting the scholarship.

\section{Literature Cited}

Addinsoft. XLSTAT: Core Statistical Software. Paris: Addinsoft, 2016. Almeida, D. P.; Resende, O.; Costa, L. M.; Mendes, U. C.; Sales, J. F. Cinética de secagem do feijão adzuki (Vigna angularis). Global Science and Technology, v.2, p.72-83, 2009.

Andrade, E. T.; Correa, P. C.; Teixeira, L. P.; Pereira, R. G.; Calomenij, F. Cinética de secagem e qualidade de sementes de feijão. Engevista, v.8, p.83-95, 2006.

Barati, E.; Esfahani, J. A. A new solution approach for simultaneous heat and mass transfer during convective drying of mango. Journal of Food Engineering, v.102, p.302-309, 2011. https://doi. org/10.1016/j.jfoodeng.2010.09.003

Bettega, R.; Rosa, J. G.; Corrêa, R. G.; Freire, J. T. Comparison of carrot (Daucus carota) drying in microwave and in vacuum microwave. Brazilian Journal of Chemical Engineering, v.31, p.403412, 2014. https://doi.org/10.1590/0104-6632.20140312s00002668
Boatright, W. L.; Hettiarachchy, N. S. Effect of lipids on soy protein isolate solubility. Journal of the American Oil Chemists Society, v.72, p.1439-1444, 1995. https://doi.org/10.1007/BF02577835

Carvalho, A. V.; Pezoa-García, N. H.; Amaya-Farfan, J. Caracterização de concentrado e isolado proteico extraído de sementes de cupuaçu (Theobroma grandiflorum Schum). Brazilian Journal of Food Technology, v.12, p.1-8, 2009.

Corrêa, P. C.; Oliveira, G. H. H.; Botelho, F. M.; Goneli, A. L. D.; Carvalho, F. M. Mathematical modeling and determination of thermodynamic properties of coffee (Coffea arabica L.) during the drying process. Revista Ceres, v.57, p.595-601, 2010. https:// doi.org/10.1590/S0034-737X2010000500005

Corrêa, P. C.; Resende, O.; Goneli, A. L. D.; Botelho, F. M.; Nogueira, B. L. Liquid diffusion coeficient determination of edible beans. Revista Brasileira de Produtos Agroindustriais, v.8, p.117-126, 2006. https://doi.org/10.15871/1517-8595/rbpa.v8n2p117-126

Costa, L. M.; Resende, O.; Sousa, K. A.; Gonçalves, S. D. Coeficiente de difusão efetivo e modelagem matemática da secagem de sementes. Revista Brasileira de Engenharia Agrícola e Ambiental, v.15, p.1089-1096, 2011. https://doi.org/10.1590/S141543662011001000014

Cyprian, O.; Nguyen, M. van; Sveinsdottir, K.; Jonsson, A.; Thorkelsson, G.; Arason, S. Influence of lipid content and blanching on capelin (Mallotus villosus) drying rate and lipid oxidation under low temperature drying. Journal of Food Process Engineering, v.3, p.404-414, 2015. https://doi.org/10.1002/fsn3.233

Doymaz, I. Drying behavior of green beans. Journal of Food Engineering, v.69, p.161-165, 2005. https://doi.org/10.1016/j. jfoodeng.2004.08.009

Ertekin, O.; Yaldiz C. Thin layer solar drying of some different vegetables. Drying Technology, v.19, p.583-596, 2001. https://doi. org/10.1081/DRT-100103936

Fellows, P. J. Food processing technology: Principles and practice. 3.ed. Cambridge: Woodhead Publishing, 2009. 928p. https://doi. org/10.1533/9781845696344

Fernandes, D. C.; Freitas, J. B.; Czeder, L. P.; Naves, M. M. V. Nutritional composition and protein value of the baru (Dipteryx alata Vog.) almond from the Brazilian Savanna. Journal of the Science of Food and Agriculture, v.90, p.1650-1655, 2010. https:// doi.org/10.1002/jsfa.3997

Gazor, H. R.; Mohsenimanesh, A. Modelling the drying kinetics of canola in fluidized bed dryer. Czech Journal Food Science, v.28, p.531-537, 2010. https://doi.org/10.17221/256/2009-CJFS 
Henderson, S. M.; Pabis, S. Grain drying theory II: Temperature effects on drying coefficients. Journal of Agricultural Engineering Research, v.6, p.169-174, 1961.

IAL - Instituto Adolfo Lutz. Métodos físico-químicos para análise de alimentos. 4.ed. Brasília: Instituto Adolfo Lutz, 2008. 1000p.

Jittanit, W. Kinetics and temperature dependent moisture diffusivities of pumpkin seeds during drying. Kasetsart Journal: Natural Science, v.45, p.147-158, 2011.

Kashaninejad, M.; Mortazavi, A.; Safekordi, A.; Tabil, L. G. Thin-layer drying characteristics and modeling of pistachio nuts. Journal of Food Engineering, v.78, p.98-108, 2007. https://doi.org/10.1016/j. jfoodeng.2005.09.007

Lima, J. C. R.; Freitas, J. B.; Czeder, L. D. P.; Fernandes, D. C.; Naves, M. M. V. Qualidade microbiológica, aceitabilidade e valor nutricional de barras de cereais formuladas com polpa e amendôa de baru. Boletim do Centro de Pesquisa de Processos de Alimentos, v.28, p.331-343, 2010. https://doi.org/10.5380/cep.v28i2.20450

Midilli, A.; Kucuk, H. Mathematical modelling of thin layer drying of pistachio by using solar energy. Energy Conversion and Management, v.44, p.1111-1122, 2003. https://doi.org/10.1016/ S0196-8904(02)00099-7

Page, G. E. Factors influencing the maximum rates of air drying shelled corn in thin layers. West Lafayette: Purdue University, 1949. 76p . Thesis

Ribeiro, E. P.; Seravalli, E. A. G. Química de alimentos. São Paulo: Edgard Blücher - Instituto Mauá de Tecnologia, 2007. 196p.

Rocha, L. S.; Santiago, R. A. C. Implicações nutricionais da polpa e castanha de baru (Diptery alata Vog.) na elaboração de pães. Ciência e Tecnologia de Alimentos, v.29, p.820-825, 2009. https:// doi.org/10.1590/S0101-20612009000400019

Rosa, D. P.; Cantú-Lozano, D.; Luna-Solano, G.; Polachini, T. C.; Telis-Romero, J. Mathematical modeling of orange seed drying kinetics. Ciência e Agrotecnologia, v.39, p.291-300, 2015. https:// doi.org/10.1590/S1413-70542015000300011

Santos, D. C.; Queiroz, A. J. M.; Figueirêdo, R. M. F.; Oliveira, E. N. A. Cinética de secagem de farinha de grãos residuais de urucum. Revista Brasileira de Engenharia Agrícola e Ambiental, v.17, p.223231, 2013. https://doi.org/10.1590/S1415-43662013000200014

Santos, P.; Aguiar, A. C.; Viganó, J.; Boeing, J. S.; Visentainer, J. V.; Martinez, J. Supercritical $\mathrm{CO}_{2}$ extraction of cumbaru oil (Dipteryx alata Vog.) assisted by ultrasound: Global yield, kinetics and fatty acid composition. The Journal of Supercritical Fluids, v.107, p.7583, 2016. https://doi.org/10.1016/j.supflu.2015.08.018
Silva, W. P.; Mata, M. E. R. M. C.; Silva, C. D. P. S.; Guedes, M. A.; Lima, A. G. B. Determinação da difusividade e da energia de ativação para feijão massacar (Vigna unguiculata (L.) Walp.), variedade sempre-verde, com base no comportamento da secagem. Engenharia Agrícola, v.28, p.325-333, 2008. https://doi. org/10.1590/S0100-69162008000200013

Sousa, A. G. O.; Fernandes, D. C.; Alves, A. M.; Freitas, J. B.; Naves, M. M. V. Nutritional quality and protein value of exotic almonds and nut from the Brazilian Savanna compared to peanut. Food Research International, v.44, p.2319-2325, 2011. https://doi. org/10.1016/j.foodres.2011.02.013

Takemoto, E.; Okada, I. A.; Garbelotti, M. L.; Tavares, M.; Pimentel, S. A. Chemical composition of seeds and oil of baru (Dipteryx alata Vog.) native from Pirenópolis, State of Goiás, Brazil. Revista do Instituto Adolfo Lutz, v.60, p.113-117, 2001.

Teixeira, P. C. M.; Zuniga, A. D. G.; Ribeiro, L. Modelagem matemática e cinética de secagem da amêndoa do baru (Dipteryx alata Vog.). Enciclopédia Biosfera, v.11, p.1309-1324, 2015.

Thompson, T. L.; Peart, R. M.; Foster, G. H. Mathematical simulation of corn drying: A new model. Transactions of American Society of Agricultural Engineers, v.11, p.582-586, 1968. https://doi. org/10.13031/2013.39473

Vega-Gálvez, A.; Miranda, M.; Díaz, L. P.; Lopez, L.; Rodriguez, K.; Scala, D. K. Effective moisture diffusivity determination and mathematical modelling of the drying curves of the olive-waste cake. Bioresource Technology, v.101, p.7265-7270, 2010. https:// doi.org/10.1016/j.biortech.2010.04.040

Vera, R.; Soares Júnior, M. S.; Naves, R. V.; Souza, E. R. B. de; Fernandes, E. P.; Caliari, M.; Leandro, W. M. Características químicas de amêndoas de barueiros (Dipteryx alata Vog.) de ocorrência natural do cerrado do estado de Goiás, Brasil. Revista Brasileira de Fruticultura, v.31, p.112-118, 2009. https://doi. org/10.1590/S0100-29452009000100017

Wang, M.; Hettiarachchy, N. S.; Qi, M.; Burks, W.; Siebenmorgen, T. Preparation and functional properties of rice bran protein isolate. Journal of Agricultural and Food Chemistry, v.47, p.411-417, 1999. https://doi.org/10.1021/jf9806964

Zogzas, N. P.; Maroulis, Z. B.; Marinos-Kouris, D. Moisture diffusivity data compilation in foodstuffs. Drying Technology, v.14, p.22252253, 1996. https://doi.org/10.1080/07373939608917205 